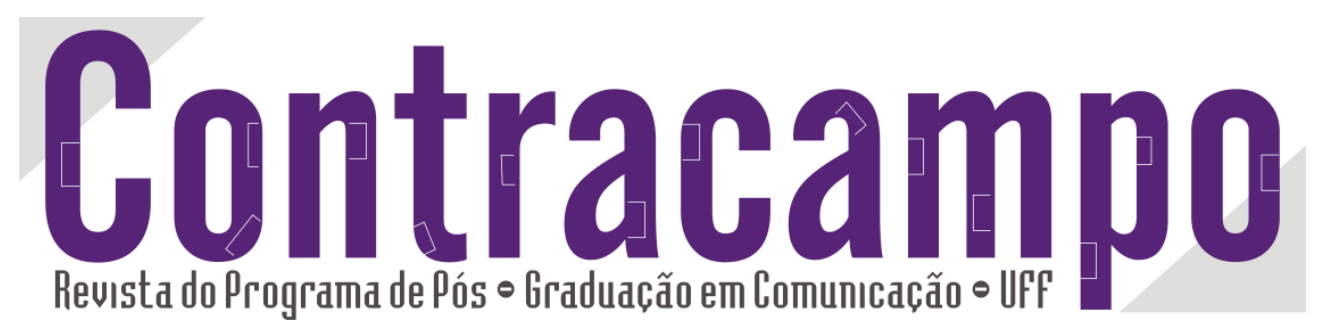

\title{
A casa e a rua no Big Brother Brasil
}

\section{The house and the street in Big Brother Brazil}

Veneza Ronsini

venezar@gmail.com

Doutora em Sociologia pela FFLCH/USP, Professora do PPG em Comunicação da UFSM/RS, pesquisadora do CNPq.

\section{PPGCOM UFF}

Ao citar este artigo, utilize a seguinte referência bibliográfica

RONSINI, Veneza. A casa e a rua no Big Brother Brasil. In: Revista Contracampo, v. 24, n. 1, ed. julho, ano 2012. Niterói: Contracampo, 2012. Pags: 266-272.

Enviado em: 27 de mar. de 2012 Aceito em: 02 de mai. De 2012

\section{Edição 24/2012 \\ Resenha}

Contracampo

Niterói (RJ), v. 24, n. 1, jul./2012.

e-ISSN 2238-2577

A Revista Contracampo é uma revista eletrônica do Programa de PósGraduação em Comunicação da Universidade Federal Fluminense e tem como objetivo contribuir para a reflexão crítica em torno do campo midiático, atuando como espaço de circulação da pesquisa e do pensamento acadêmico. 


\section{Resumo}

Resenha do livro Bruno Campanella. Os olhos do Grande Irmão. Uma etnografia dos fãs do Big Brother Brasil. Porto Alegre:Sulina, 2012.

Palavras-chave: Reality show. Fãs. Etnografia.

\section{Abstract}

Critical review of the book by Bruno Campanella. The eyes of the Big Brother. A ethnography of Big Brother's fans.Porto Alegre:Sulina, 2012.

Keywords: Reality show. Fans. Ethnography.

A tese de doutoramento, vencedora o prêmio Compós 2011, que deu origem ao livro de Campanella combina a abordagem da recepção com o exame das interações entre os participantes do reality show BBB para discutir questões amplas da cultura e da sociedade brasileira. O modo de olhar nos olhos do Grande Irmão ilumina inovadoramente a problemática dos poderes da mídia e os contrapoderes da audiência. Além disso, recupera questões já trabalhadas internacionalmente como o embaralhamento das fronteiras entre o público e o privado em estudos sobre a participação de pessoas ordinárias em talk shows (LIVINGSTONE, LUNT, 1996; GRINDSTAFF, 2002); ou em reality shows, de acordo com a ampla bibliografia utilizada pelo próprio autor.

Trata-se de ter fôlego para analisar duplamente o programa e sua recepção em um cenário de pouquíssimos estudos de recepção endereçados ao exame da internet. Entre 2000 e 2009, das 5644 teses e dissertações defendidas nos Programas de Pós-Graduação brasileiros, em um levantamento ainda incompleto, 165 são estudos empíricos de recepção, dos quais 49 adotaram uma abordagem sociocultural e 62 uma abordagem sociodiscursiva (JACKS et al., 2011, p.80-86). A internet é contemplada em quatro pesquisas na primeira e em cinco na segunda. 
Ao invés de uma análise discursiva ou textual do programa, opta por observar o modo pelo qual os participantes se afirmam como jogadores na casa. No campo da recepção, realiza uma etnografia e uma netnografia realizando entrevistas presenciais, aplicando questionários e escrevendo um diário de campo como participante de blogs e fóruns relativos à oitava edição do BBB.

O estudo também se destaca em relação aos estudos da internet realizados internacionalmente, os quais (LIVINGSTONE e PRESS apud KNEWITZ, 2009, p. 5) seguem duas tendências: a primeira estuda a formação das identidades em comunidades on-line em uma perspectiva textual; a segunda estuda as apropriações da internet na vida cotidiana sem preocupações com o conteúdo daquilo que é apropriado. Por um lado, estuda as identidades, a partir das interações e das apropriações do Programa e seus desdobramentos na internet, por outro, articula as discussões na web com as interações na casa.

No Brasil ${ }^{1}$, um problema comum a muitos trabalhos que investigam as relações entre usuários e internet é seu distanciamento em relação à preocupação central dos estudos culturais latino-americanos acerca do papel que a cultura tem no exercício da hegemonia, enquanto os trabalhos mais próximos da cibercultura têm como característica apontar as transformações no gerenciamento das subjetividades e das identidades (empiricamente ou como pressuposto teórico observável nos produtos da mídia ou nas interações entre mídia e indivíduos), mas sem explicar como se dá esta articulação entre as macroestruturas e sujeito. Vale dizer, não há uma interpretação da leitura que o usuário faz dos conteúdos da web e as conclusões a respeito da produção na web pelos agentes se baseiam mais na teoria do que propriamente em evidências empíricas.

A pesquisa de Campanella, entretanto, tal como outras investigações sobre as interações na web (BRAGA, 2008; CASTELLANO, 2011 e BRIGNOL, 2004) estão atentas ao exame da constituição das identidades e permitem compreender as

\footnotetext{
${ }^{1}$ Embora não se possa generalizar com um levantamento despretensioso e sem relevância estatística como o que fiz na leitura de apenas 18 trabalhos da década de 2000 (OLIVEIRA, 2009; MATSUZAKI, 2009; BANDEIRA, 2009; BERSCH, 2009; CASTELLANO,2009; FERREIRA, 2009; Dal BELLO, 2009; BREDARIOLI, 2008;. ZHANG,, 2007; MOHERDAUI, 2005;. LINKE, 2005; VIANA, 2005; BRIGNOL, 2004;GALARÇA, 2004;GOUVEIA,2004; SIMÕES, 2004;ROCHA, 2003). A tese de doutorado de BRAGA está citada nas referências porque foi publicada, enquanto as demais estão referenciadas apenas aqui, por motivo de espaço.
} 
interpretações das audiências/usuários dentro de um amplo quadro analítico da cultura e do poder.

\section{Um etnógrafo visível aos olhos da audiência}

Coerente com sua compreensão de comunidade virtual como espaço de compartilhamento do sentido, ele se deixa ver pelos outros explicitando seus interesses de pesquisador-participante e observador do fórum BBB.Lua e dos blogs. Muito interessante é o seu relato sobre a importância do link para o currículo Lattes do pesquisador como elemento de confiança para superar a desconfiança em relação ao sigilo das identidades reais dos informantes, preocupados com o impacto negativo que sua revelação poderia ter na imagem deles no ambiente de trabalho, em função dos vínculos que o senso comum faz entre a "baixa qualidade" do Big Brother e o suposto mau gosto de quem o assiste.

É com a habilidade de um etnógrafo que o comunicólogo se aproxima do objeto tentando compreender o que leva os fãs do programa a participarem ativamente de um debate acerca dos confinados - a partir do ponto de vista deles mesmos sem deixar de considerar as críticas teóricas contundentes aos realities. Ele nos mostra que o mais interessante é perceber as perspectivas dos fãs e suas inter-relações com a sociedade brasileira, partindo do fato de que tanto a web fortalece as empresas quanto encoraja uma comunicação comunitária (CABRAL FILHO, 2011, p.156-157).

Em uma prosa fluente, somos guiados a compreender as disputas dos fãs pela legitimação de capital cultural, os critérios utilizados para avaliar a atuação dos

postulantes ao prêmio, as mediações de categorias como classe, raça, gênero e identidade regional e seus impactos nas leituras da audiência, a conformação particular do processo de individualização em nosso país.

\section{A percepção dos fãs e o cotidiano na casa}

Os fãs articulam duas maneiras diferentes de avaliar o cotidiano da casa, uma é relacionar o que se passa na casa com um jogo no qual vence o indivíduo capaz de combinar estratégia com autenticidade (CAMPANELLA, 2012, p. 75), outra é 
interpretar o jogo através da experiência social dos confinados usando para tal categorias como região, classe, gênero.

$\mathrm{Na}$ avaliação do jogo o que conta é a rotina de convivência, as tarefas cotidianas, o comportamento nas festas, as brincadeiras e conversas, além da performance nas competições entre os candidatos aos prêmios. $\mathrm{O}$ apagamento da trajetória na rua (aqui uma metáfora para falar da vida fora da casa) é uma condição para o bom julgamento sobre quem deve vencer, pois o que conta são as qualidades da resistência, sociabilidade entre os membros, inteligência, ética e autenticidade. Neste caso, estas qualidades devem ofuscar aspectos que associem o candidato a fatores como classe, raça, identidade. Este critério parece ter a aprovação da produção do programa na medida em que deixou de usar o modelo de seleção por sorteio, o qual resultou na seleção de pessoas pobres para a quarta e a sexta edições, que foram eleitos pelo público como ganhadores do BBB, em grande parte pelo passado comum de dificuldades econômicas (ibidem, p. 86).

As duas últimas edições do Big Brother seguem a tendência apontada por Campanella ao reproduzir uma fala de Pedro Bial a de evitar fazer "justiça social por meio de um programa de TV". Não houve participante de classe popular, a julgar pelas profissões das mulheres, entre outras, promotora de eventos, secretária executiva, estudante de medicina e modelo, arte-educadora, estudante de administração, cabeleireira e pelas profissões dos homens: administrador, engenheiro, projetista de iluminação, modelos, comerciante, fazendeiro, vendedor, professor de artes marciais, veterinário, músico, estudante, etc.

$\mathrm{Na}$ avaliação dos fãs mediante referências sociais fica evidente que a individualização à brasileira não prescinde de categorias sociais para o julgamento da identidade. Os indicadores empíricos demonstram que ora é a origem racial, de classe ou regional do participante emerge como elemento de tensão entre os fãs, ora comportamento feminino mais tradicional ou independente.

Finalmente, a investigação demonstra como a disputa entre os fãs pela legitimidade de seus comentários na web é uma luta por capital cultural norteada por fatores como popularidade, autonomia em relação à produção do programa, reconhecimento dos blogs pela mídia de massa, etc. A criativa investigação mostra-nos 
conclusões não tão sombrias como as que pensam o mundo digital como a decadência, nem tão otimistas como as que imaginam um self autônomo.

\section{Considerações finais}

É um olhar como este, para além do olhar nos olhos do Grande Irmão, mas voltado para a investigação da recepção como questão social e cultural que poderemos refinar o sentido da mídia no cotidiano dos receptores para além da uma submissão ou resistência às leis do mercado. Neste trabalho, a riqueza consiste em mostrar, por um lado, as evidências de um arrebatamento dos fãs pela ética da autenticidade, essa idéia persistente de que existe uma interioridade original que merece ser preservada das forças externas (CAMPANELLA, 2012, p. 162); por outro, no envolvimento com Big Brother Brasil, alguns fãs exercitam ideais de libertação feminina, combatem preconceitos raciais e de classe, refletem sobre disparidades regionais. Como afirma Livingstone e Lunt (1996, p. 71) o receptor crítico é aquele que apresenta argumentos e não quem simplesmente rejeita os programas televisivos.

Para além da crítica, em tempos de insegurança ontológica, quem sabe, tal como os jovens na percepção de Martín-Barbero (2004), o que também se quer no mundo virtual é estar junto, compartilhar emoções e palavras para fugir ao isolamento provocado pelo peso que o mundo colocado sobre nossos ombros provoca, vale dizer, pela responsabilização individual dos nossos fracassos e vitórias. $\mathrm{O}$ ritual do encontro na rede torna menos árido o deserto existencial.

\section{Referências bibliográficas}

BRAGA, Adriana. Personas materno-eletrônicas. Feminilidade e interação no blog Mothern. Porto Alegre: Sulina, 2008.

BRIGNOL, Liliane. Identidade cultural gaúcha nos usos sociais da internet: um estudo de caso sobre a página do gaúcho. Dissertação (Mestrado em Ciências da Comunicação)- Centro de Ciências da Comunicação, Universidade do Vale do Rio dos Sinos, São Leopoldo, 2004.

CABRAL FILHO, Adilson. A web 2.0 como agenciamento de audiências pelos grupos midiáticos contemporâneos. LOGOS 34, Vol.34, Nº1,p. 152-165, $1^{\circ}$ semestre 2011. 
CASTELLANO, Mayka.. Reciclando o "lixo cultural": uma análise sobre o consumo trash entre os jovens. (Mestrado em Comunicação e cultural) - Escola de Comunicação, Universidade Federal do Rio de Janeiro, Rio de Janeiro, 2009.

GRINDSTAFF, Laura. The Money shot. Trash, class and the making of TV talk shows. Chicago: University of Chicago, 2002.

JACKS, Nilda et. al. Pesquisa sobre audiências no Brasil: primórdios, consolidação e novos desafios. In JACKS, Nilda et al. (coord./editora) Análisis de recepción em America Latina: um recuento histórico com perspectiva al futuro. Quito: Ed. Quipus/CIESPAL, 2011, p.69 102.

KNEWITZ, Anna P. Estudos culturais e cibercultura. Um entrelaçamento teóricometodológico necessário para pensar a recepção na Web. XVIII Encontro da Compós, na PUC-MG, Belo Horizonte, MG, em junho de 2009.

LIVINGSTONE, Sonia; LUNT, Peter. Talk on television. Audience participation and public debate. London: Routledge, 1996.

MARTÍN-BARBERO, Jesús. Crisis identitarias e transformaciones de la subjetividad. Disponível em http://www.mediaciones.net/2004/01/crisis-identitarias-y-transformaciones-dela-subjetividad/ Capturado em 22 de abril de 2012. 